\section{The Influence of Corporate Governance on the Mitigation of Fraudulent Financial Reporting}

\author{
Orleans Silva Martins ${ }^{1}$ \\ ${ }^{1}$ Federal University of Paraiba, Department of Finance and \\ Accounting, João PessoalPB, Brazil \\ Raul Ventura Júnior ${ }^{1}$ \\ ${ }^{2}$ Federal University of Campina Grande, Academic Unit of \\ Accounting, Sousa/PB, Brazil
}

Received on

03/09/2018

Approved on

04/11/2019

Responsible editor:

Prof. Dr. Ivam Ricardo Peleias

Evaluation process:

Double Blind Review

\begin{abstract}
Purpose - This study analyzes the influence of the corporate governance structure in terms of mitigating the likelihood of fraudulent financial reporting (FFR) by firms in Brazil.

Design/methodology/approach - For this, we analyze the data of 314 publicly traded companies to estimate the likelihood of bankruptcy and the possibility of earnings manipulation, for subsequent identification of .

Findings - Our results show that in $5.5 \%$ of cases there is an indication that FFR is likely, bankruptcy is predicted in $16.9 \%$ of cases, and the likelihood of earnings manipulation is identified in $17.7 \%$. The corporate governance structure of the firms influences FFR mitigation, either directly or indirectly by reducing the chances of bankruptcy or earnings manipulation. We note that board-related governance practices are more effective against predicted bankruptcy, and auditrelated practices are more related to reducing earnings manipulation.

Originality/value - The main contributions of this study lie in it identifying the probabilities of reporting fraud, bankruptcy, and earnings manipulation for companies in Brazil, as well as it verifying that corporate governance has been effective in mitigating these problems, either directly or indirectly. Thus, this information is useful for investors and regulators in this market.
\end{abstract}

Keywords - Insolvency; Financial Reports; Frauds; Corporate Governance.

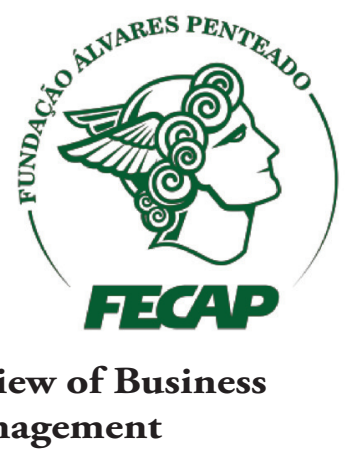

DOI:10.7819/rbgn.v22i1.4039 


\section{Introduction}

The growth of companies and the complexity of corporate environments have fostered the separation between the ownership and control of these companies. With this process, the owners (the principals) began to delegate the management of their properties to third parties (the agents), in the expectation that the latter would act in the best interests of the companies. However, because this delegation of power can be supported by imperfect contracts (Jensen \& Meckling, 1976), conflicts of interest arise between principals and agents, which allow for information asymmetry to occur. Moreover, for Jensen and Meckling (1976), this problem represents a discrepancy in scope not only in the quantity but also in the quality of the information available to capital market players.

The problem of information asymmetry in any given market can occur at two moments: it can involve opportunistic actions ex-ante the disclosure of information (adverse selection) or expost (moral hazard). Given this, Murcia, Borba, and Schiehll (2008) highlight fraud as one of the consequences of this asymmetry, and it may be linked to misconduct, involving illicit practices and bad faith, as well as being difficult to identify, due to the timing of those who carry it out, with a view to achieving their personal interests, regardless of the damage that such actions will cause to third parties.

Wells (2011) states that when fraud involves financial reporting, the causes are related to several factors at the same time, one of the most significant being the pressure on management to achieve better results, where executives can manipulate financial records for the primary purpose of hiding the firm's real performance, thereby maintaining their position, control, and income as reflected in wages, bonuses, and equities. Cunha, Silva, and Fernandes (2013) note that scandals involving financial reporting by reputable companies are common, such as the cases of WorldCom, Enron, Xerox, Delphi
Corporation, Global Crossing, and Adelphia, among others. These cases have resulted in a crisis of confidence in capital markets around the world, leading to the diminishing credibility of the information extracted from financial reports by the participants in these markets.

The most common way to try to inhibit such opportunistic actions is through regulation. After the occurrence of such cases, for example, the Sarbanes-Oxley Law (SOX) emerged in the United States market, aiming to attest to the reliability of information and to impose sanctions on those who commit such offenses (Cunha, Silva, \& Fernandes, 2013). In addition, corporate governance practices stand out, as they have a great responsibility to the corporate function and the perception of red flags issued by internal controls (Jensen, 1993), which can identify a situation of adverse selection or moral hazard, reducing information asymmetry and improving the quality and/or quantity of information published through financial statements.

In Brazil, a number of financial scandals have occurred in large companies, such as the cases involving Panamericano Bank (in 2010), OGX (in 2012), and Petrobrás (in 2014). At Panamericano Bank, the scandal was directly related to its accounting reports, as the financial institution used the trick of recording among its assets loan portfolios already sold to other banks. The case was made public in 2010, highlighting the lack of reliability in auditing to identify fraud in financial reporting (Coelho, Lima, Souza, Oliveira, \& Oliveira, 2015).

Regarding corporate governance, Beasley (1996) points out its importance in reducing the incidence of fraudulent financial information. For Dalmácio and Rezende (2008), governance enables information to be timely, credible, and of quality. This is supported by Razali and Arshad (2014), when they state that governance is a means of mitigating conflicts of interest, as it represents a set of tools that reduces opportunistic attitudes and may inhibit actions that lead companies' financial reports to become 
fraudulent. This observation is in line with Perera, Freitas, and Imoniana (2014), who report that information asymmetry can be considered as being at the core of these corporate frauds, as it allows opportunities for the agent (moral hazard) to perpetrate fraudulent actions in companies, seeking to maximize their own benefits.

Due to the difficulty in identifying its characteristics, the impacts of fraud may be greater in environments with no investor control or monitoring, which favors its occurrence. Thus, Razali and Arshad (2014) note that it can be detected by internal controls that, through the observation of signs (red flags), make minimizing, or even inhibiting, its negative impacts on investors and other stakeholders more likely. To identify whether a company is likely to be cheating in its financial reports, Razali and Arshad (2014) used a metric that considers the likelihood of bankruptcy and of accruals at the same time, assuming that companies that are struggling financially to continue to attract market attention may perform illegal manipulations of their financial reports to improve their bottom line. Thus, it is possible to identify the likelihood of fraudulent financial reporting (FFR).

In this context, Law (2011) shows that cases of fraud around the world destroy confidence in financial information and, consequently, in the financial market, hence undermining confidence in the very image of the accounting profession. Thus, motivated by a history of financial reporting fraud in Brazil and by the unique opportunity that this market offers to study the effects of differentiated levels of corporate governance (DLCG) on FFR, this study aims to analyze the influence of the corporate governance structure in terms of mitigating the likelihood of FFR by publicly traded companies in Brazil between 2010 and 2015.

Our main findings demonstrate that the practices that make up the corporate governance structure of firms are effective in mitigating FFR, especially because some of these practices are negatively associated with the likelihood of bankruptcy, and other practices have a negative influence on the likelihood of earnings manipulation. Moreover, we provide advances in the literature in relation to the study by Razali and Arshad (2014), since we use a bankruptcy prediction model adjusted to the Brazilian market by Altman, Baydia, and Dias (1979). In addition, for both Z-score and $\mathrm{M}$-score, new parameter estimates are made for the sample under consideration, looking to the current context of the Brazilian market. Another important differential of this study is the use of probabilistic models to estimate the probabilities of bankruptcy and earnings manipulation in companies, in order to subsequently identify the likelihood of FFR, which increases the robustness of our findings.

Above all, in addition to this methodological contribution, we highlight the contributions to the literature, since we did not identify any previous study that analyzed FFR in this market, besides the methodological robustness and relevance of the findings, which are useful to investors and market regulators, since it is possible to identify the probabilities of reporting fraud, bankruptcy, and earnings manipulation, and it is possible to find that corporate governance is effective in mitigating these problems.

\section{Literature Review}

\section{I Fraudulent Financial Reporting}

While financial reporting is one of the key sources for extracting information that supports investment decision making, the scams that have involved such reporting in recent decades have generated several misgivings about accounting. According to Murcia and Borba (2005), accounting fraud has triggered negative financial effects on capital markets, affecting the investment decisions of shareholders and stakeholders, and impacting the economies of countries by increasing distrust, leading firms to bankruptcy and, therefore, to the emergence of layoffs, as in the case of Enron in the US market. 
Murcia and Borba (2005) also note that as of the 2000s, scandal disclosures involving companies such as WorldCom (in 2002) and Parmalat (in 2003) have also increased exposure to market fragility due to accounting frauds carried out by company managers and others responsible for preparing distorted information (smoothing effect), a phenomenon known as creative accounting, which causes the quality and reliability of financial reports to decrease.

For Silva (2007), the cases of fraud involving financial reporting and the impacts that these acts may have on the market have resulted in an intense debate about how financial information is generated and disclosed, as these illicit attitudes reflect behavioral elements, including ethics, morals, and good faith. For this reason, it is also possible to relate the occurrence of fraud in financial reporting to deviations in the behavior of managers, which are related to the agency problem dealt with by Agency Theory (Jensen \& Meckling, 1976). Once there is evidence of moral hazard there will be a need for constant monitoring by the firm to prevent such behavior and FFR (Perera, Freitas, \& Imoniana, 2014).

According to Murcia and Borba (2005), accounting frauds are most often carried out by firm managers or executives, with the aim of benefiting companies through the disclosure of manipulated reports, increasing company results so that there is a positive impact on the stock market. This is supported by Dechow, Ge, Larson, and Sloan (2011), who analyzed 2,190 US companies between 1982 and 2005 and found that firms classified as manipulative tended to have liquidity problems. Also, the empirical results found by Mehta and Bhavani (2017) showed that the Japanese firm Toshiba, in its period of fraud, had characteristics of being manipulative and having problems of continuity at the same time. This suggests that such problems may be intrinsically related, especially when the company commits fraud.

Therefore, in this study, as in that of Razali and Arshad (2014), the likelihood of FFR is observed by simultaneously identifying the risk of imminent bankruptcy and the possibility of the company being an earnings manipulator. To predict bankruptcy and identify the likelihood of earnings manipulation, these authors estimated the $\mathrm{Z}$-score and $\mathrm{M}$-score based on the Altman (1968) and Beneish (1999) models, respectively. However, in the Brazilian context, Silva et al. (2012) point out that the Z-score directly estimated by Altman, Baydia, and Dias (1979) in the Brazilian market is a predictive measure of bankruptcy with a higher predictive power. For this reason, in this study, that model is used to identify the Z-score.

These models are often used in the literature to predict bankruptcy and identify earnings manipulation, respectively, by estimating the $\mathrm{Z}$-score and $\mathrm{M}$-score. Among these studies, Silva et al. (2012) analyzed the predictive power of various bankruptcy prediction models with a sample of 13 Brazilian companies that declared bankruptcy between 1997 and 2003. The main findings of these authors demonstrated that, among the models studied, the Z-score estimated by Altman, Baydia, and Dias (1979) obtained the highest predictive power, with 100\% accuracy. Arshad, Iqbal, and Omar (2015) analyzed the predictability of the Z-score and M-score, comparing the financial information of 48 Malaysian firms, including 24 failed companies. The findings of these authors indicate that their model was reliable by classifying approximately $96 \%$ of the total sample as predictors of business failure, and approximately $83.3 \%$ as predictors of FFR, and predicting the relationship between business failures and fraudulent financial reports.

Tajo and Herawati (2015) also analyzed the reliability of the $\mathrm{M}$-score, comparing information from 35 fraud-committing and 35 non-fraud-committing companies, all located in Indonesia, between 2001 and 2014. Data mining and logistic regression were used for this analysis, and the results indicated $77.1 \%$ accuracy for the classification of companies that engaged in manipulation and $80 \%$ for firms that did not 
engage in it. Kamal, Salleh, and Ahmad (2016) tested the predictive ability of the M-score in 17 Malaysian companies before their managers were prosecuted for committing fraud and accounting misstatements from 1996 to 2014 . These findings suggest that the model is reliable, with $82 \%$ accuracy in the classification of firms.

Therefore, these predictive models (Z-score and $M$-score) have been used in different studies that may be related to FFR. Additionally, we note that different corporate governance practices also relate to bankruptcy prediction and earnings manipulation (Omar, Koya, Sanusi, \& Shafie, 2014; Arshad, Razali, \& Bakar, 2014; Razali \& Arshad, 2014). Thus, in this study, these metrics are used to analyze the effectiveness of the corporate governance structure against fraud in companies' financial reports.

\subsection{Corporate Governance as a Fraud Inhibitor}

According to Peleias, Segreti, and Costa (2009), corporate governance is a means of resolving conflicts of interest between principal and agent, especially through basic principles of transparency, via the disclosure of financial information. Additionally, it is noted that corporate governance is an important practice for reducing the informational asymmetry present in stock market trading and may inhibit the opportunistic actions of insiders (Moreira, Tabosi Filho, \& Gargia, 2012; Piccoli, Souza, \& Silva, 2014; Martins \& Paulo, 2014).

Regarding corporate governance structure, this paper considered the practices that have the potential to influence companies' financial reports, as follows: the size of the board of directors (Alzoubi \& Selamat, 2012; Razali \& Arshad, 2014); the participation of independent members (Siladi, 2006) and women in this board (Boulouta, 2013); the average compensation of this board (Oliva \& Albuquerque, 2007; Hermalin \& Weisbach, 2012); the non-duality of the positions of Chief Executive Officer (CEO) and Chairman of the Board (Chhaochharia \&
Grinstein, 2009); the audit committee (Coram, Ferguson, \& Moroney, 2006); and independent audits (Silva, Braga, \& Laurencel, 2009; Santos, Martins, Martins, Santos Neta, \& Chain, 2013), which are important for red flag detection.

The size of the board of directors is considered a best corporate governance practice because, according to Alzoubi and Selamat (2012), in the finance literature there are studies that relate the reduction of informational asymmetry to characteristics such as the size of the board and the effectiveness of control, suggesting that the smaller the board, the better the control of the firm, as there is more efficient communication between its members (Abbott, Parker, \& Peters, 2004; Alzoubi \& Selamat, 2012). However, very small boards can undermine the efficiency of examinations and decisions, so around 8 or 9 members are recommended (Lipton \& Lorsch, 1992; Vafeas, 2005). In Brazil, Holtz and Sarlo Neto (2014) identified that companies have an average of 7 members on their boards. Therefore, a company having between 5 and 9 members on its board is considered a good governance practice.

The independence of the members of this board is also a relevant factor among governance practices. According to Xie, Davidson, and Dadalt (2003), such independence improves the effectiveness of management monitoring and also reduces the likelihood of earnings management. For Siladi (2006), this independence should reflect non-involvement in the day-to-day operating of the organization, but proximity of the advisors to the company's executive team, in order to obtain more information and knowledge about the company. Razali and Arshad (2014) explain that this "non-involvement in day-to-day operations" reflects non-submission to internal pressures, with independent members more likely to act in line with investors' interests, contributing to the reduction of information asymmetry. Therefore, higher independence is a good governance practice.

The participation of women on the board of directors is also an element considered to be 
relevant to the corporate governance structure. According to Boulouta (2013), when there are women on the board their performance tends to achieve better results. In Brazil, the Code of Best Practices of Corporate Governance of the Brazilian Institute of Corporate Governance (IBGC, 2015) recommends that, for a better quality board, there should be a plurality not only of competences but also of genders. Such plurality is related to the board's performance in terms of understanding individual characteristics among its members, resulting in richer debates and, as a result, safer and better-quality decision making. For this reason, the presence of women on the board is seen as a good practice.

The compensation of the board of directors is another relevant element to align shareholders' objectives with those of managers. Compensation can be linked to the company's results, serving as an incentive for the managers to contribute to increases in shareholder wealth (Oliva \& Albuquerque, 2007). Regarding information asymmetry, Hermalin and Weisbach (2012) note that some mandatory increases in company disclosure can partly be explained by increases in senior management compensation. Therefore, higher compensation is expected to be related to a reduction in conflicts of interest and information asymmetry.

The dual role of CEO and Chairman positions is another element to note in the corporate governance framework. As Bebchuk and Fried (2004) point out, the board of directors is limited in terms of being able to intervene in corporate decisions made by the CEO regarding the alignment of interests between agents and principals. Thus, if the CEO assumes the role of Chairman, he/she can concentrate managerial power, making it possible to make unilateral decisions, or influence some board decisions to accept compensation not linked to the operating performance of the corporation, or even raise the value of such compensation above a reasonable level (Chhaochharia \& Grinstein, 2009).

The audit committee is an important element of a company's governance structure as it reviews the independence and integrity of the firm's financial reports (Law, 2011). For Coram, Ferguson, and Moroney (2006), this committee is an instrument for preventing earnings management. And according to Razali and Arshad (2014), a strong audit committee is able to promote impartial assessment and judgment, as well as better, more effective monitoring of company management, by inhibiting the occurrence of fraud in its financial reports. Therefore, it is reasonable to expect larger committees to have greater analytical capacity and efficiency, as pointed out by Ken, Routledgea, and Steward (2010), who note that their size influences the quality of financial statements, because the larger they are, the greater their diversity of knowledge and effectiveness.

External (or independent) auditing is also an important control element that firms use to bolster the quality of their financial statements. It is also indispensable for users of accounting information, as it represents an external agent to the organization, acting independently and issuing an impartial opinion on the company's results (Silva, Braga, \& Laurencel, 2009; Santos et al., 2013; Santana, Bezerra, Teixeira, \& Cunha, 2014). Therefore, better independent auditing leads to a lower likelihood of FFR. And one parameter of the quality of the audit is the price paid for it (weighted by company size), because better inspections and more dedicated staff require higher compensation. This observation coincides with that of DeAngelo (1981), who argues that there are incentives for larger audit firms to offer differentiated quality services when fees are higher. Moreover, for Francis (1984), in a competitive market, better quality audit services will have the highest fee values.

Finally, it is noteworthy that the advent of differentiated levels of corporate governance in the Brazilian stock exchange has created an environment that is conducive to analyzing the reflection of such practices in the quality of corporate reporting (Piccoli et al., 2014). When a company voluntarily submits to listing in the 
New Market segment of corporate governance, it is understood that it has an additional commitment to the quality of its management and, consequently, to the disclosure of its results, reflecting a greater degree of investor protection (Martins \& Paulo, 2014). And such a listing has a negative relationship with earnings management and information asymmetry in the Brazilian market (Moreira et al., 2012; Piccoli et al., 2014). Therefore, this study considers the relationship between such a listing and the likelihood of fraudulent financial reports.

Table 1 summarizes the expected influence of each corporate governance variable on the likelihood of FFR.

Table 1

Expected influences of the corporate governance structure variables.

\begin{tabular}{|c|c|c|}
\hline Variable & $\begin{array}{l}\text { Expected } \\
\text { influence }\end{array}$ & Reference \\
\hline Board Size (Bsize) & - & $\begin{array}{l}\text { Lipton and Lorsch (1992), Vafeas (2005), Alzoubi and } \\
\text { Selamat (2012), and Razali and Arshad (2014) }\end{array}$ \\
\hline Board Independence (Bind) & - & $\begin{array}{c}\text { Xie, Davidson, and Dadalt (2003), Siladi (2006), } \\
\text { and Razali and Arshad (2014) }\end{array}$ \\
\hline Women on the Board (Bwom) & - & Boulouta (2013) \\
\hline Non-duality of CEO and Chairman (Ndual) & - & $\begin{array}{l}\text { Bebchuk and Fried (2004) and Chhaochharia and } \\
\text { Grinstein (2009) }\end{array}$ \\
\hline Board Compensation (Bcom) & - & $\begin{array}{c}\text { Oliva e Albuquerque (2007) and Hermalin and } \\
\text { Weisbach (2012) }\end{array}$ \\
\hline External Audit Compensation (EAcom) & - & $\begin{array}{c}\text { DeAngelo (1981), Francis (1984), and } \\
\text { Santana et al. (2014) }\end{array}$ \\
\hline Audit Committee Size (ACsize) & - & $\begin{array}{l}\text { Coram, Ferguson, and Moroney (2006) and } \\
\text { Law (2011) }\end{array}$ \\
\hline New Market Listing (NMlist) & - & $\begin{array}{l}\text { Moreira et al. (2012), Piccoli et al. (2014), } \\
\text { and Martins and Paulo (2014) }\end{array}$ \\
\hline
\end{tabular}

\section{Method}

This study analyzes a sample of public companies listed on the Bolsa, Brasil, Balcão $\left(\mathrm{B}^{3}\right)$ exchange. We collected financial data available from the Thomson Reuters database for the 314 companies listed in that database between 2010 and 2015. Then, firms with missing data for any of the variables analyzed, as well as companies in the financial sector, were excluded from the sample because they present differences in their financial structure, which would skew the analysis. The total sample contained 1,451 companyyear observations. The data on the corporate governance of these firms were taken from the Comdinheiro database. 


\section{I Identification of Likelihood of Fraud}

The likelihood of FFR is represented by a binary variable, as in Razali and Arshad (2014), derived from the mutual identification of predicted bankruptcy (Z-score) and the likelihood of earnings manipulation (M-score), as shown in Figure 1. However, an important advance made by this study is that FFR is identified from the probability of the company having Z-score and M-score values similar to the subsamples of companies with problems of continuity or preparation of their financial statements. Therefore, the firms' Z-scores and $\mathrm{M}$-scores are calculated and identified as $P\left(Z_{i}=1\right)$ and $P\left(M_{i}=1\right)$, which are, respectively, the likelihood pf the firm having characteristics similar to the group of firms with problems of continuity, or to the group with a history of rewriting and republishing their financial statements.

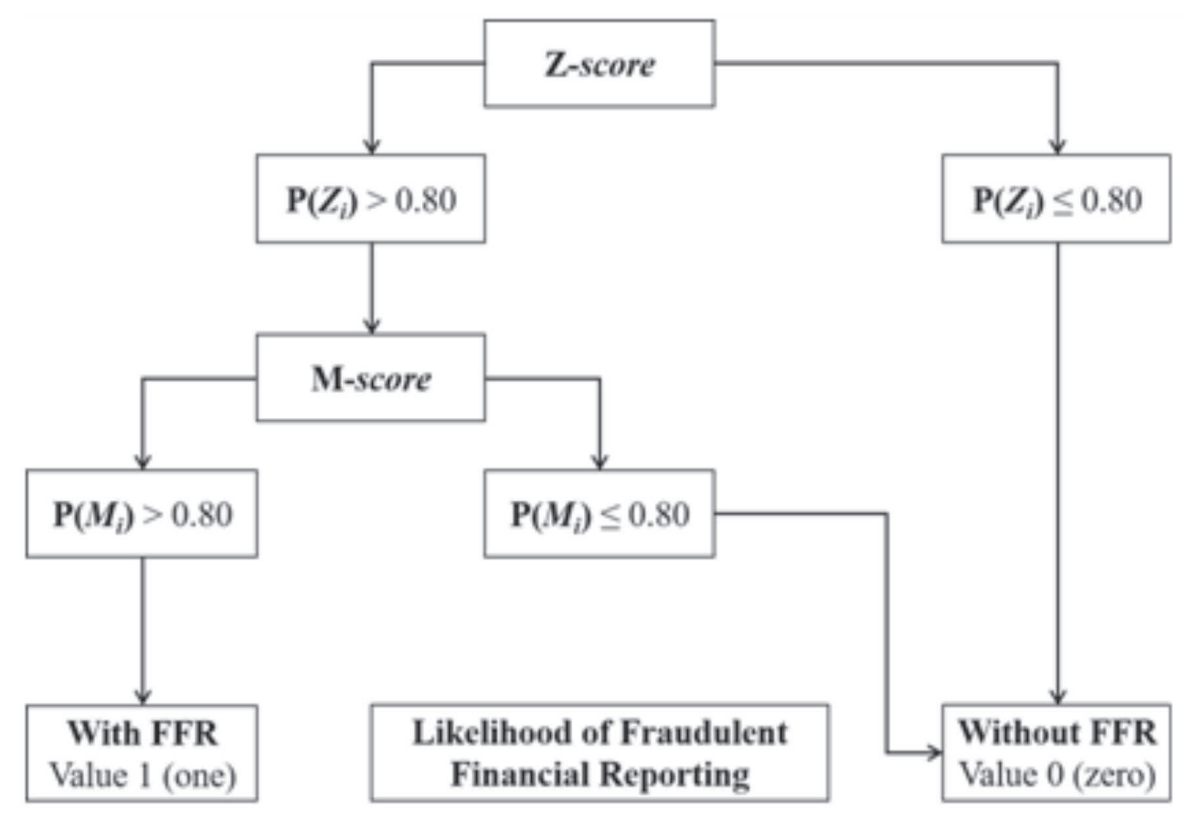

Figure 1. Identification of likelihood of Fraudulent Financial Reporting (FFR) Source: The authors, based on Razali and Arshad (2014).

To analyze the relationship between and corporate governance structure, we use probit bivariate regression models, with pooled panel data, according to Equation 1. For this estimation, the variables were winsorized by $1 \%$ to avoid the effect of outliers on the variables.

$$
\begin{gathered}
\ln \left(\frac{p_{i t}}{1-p_{i t}}\right)=\boldsymbol{P}\left(\boldsymbol{Y}_{i t}=\mathbf{1}\right)=\beta_{0}+\beta_{1} \text { Bsize }_{i t}+\beta_{2} \text { Bind }_{i t}+\beta_{3} \text { Bcom }_{i t}+\beta_{4} \text { Ndual }_{i t}+\beta_{5} \text { Bwom }_{i t}+ \\
\beta_{6} \text { ACsize }_{i t}+\beta_{7} \text { EAcom }_{i t}+\beta_{8} \text { NMlist }_{i t}+\beta_{9} \text { SIZE }_{i t}+\delta_{t}+\gamma_{s}
\end{gathered}
$$

For every firm $i$ in period $t, \boldsymbol{Y}_{i t}$ is a binary variable that indicates the likelihood of FFR in model 1 , the bankruptcy prediction $\left(P\left(Z_{i}\right)>0.80\right)$ in model 2, and the earnings manipulation $\left(P\left(M_{i}\right)>0.80\right)$ in model 3 ; $B$ size $e_{i t}$ indicates that the company has between 5 and 9 members on the board of directors; Bind $_{i t}$ is the percentage of independent directors on this board; Bcom $_{i t}$ is the total compensation of the directors, weighted by total assets; $N d u a l_{i t}$ indicates no duality of CEO 
and Chairman positions, assuming a value of 1 (one) in the case of non-duality and 0 (zero) otherwise; Bwom is the percentage of women on the board; $A C s i z e_{i t}$ is the number of members on the audit committee; $E_{\text {Acom }}$ it is the total amount paid to independent auditing firms, weighted by total assets; NMlist it is the company's listing in the New Market segment; $S I Z E_{i t}$ is the logarithm of total assets; and $\delta t$ and $\gamma_{s}$ are, respectively, fixed effects for year and sector.

\subsection{Identification of Bankruptcy Prediction and Earnings Manipulation}

The Z-score developed by Altman (1968) is usually applied to studies on bankruptcy prediction. This same author presents a derivation of the model for emerging countries, in which the volume of bankruptcies tends to be higher, applying it directly to the Brazilian market (Altman, Baydia, \& Dias, 1979). The authors regressed an indicator variable of firms in bankruptcy or judicial reorganization for their financial characteristics, and arrived at an equation that indicated the chance of a company becoming insolvent, given by $Z i=-1,84-0,51 X_{1}+6,32 X_{3}$ $+0,71 X_{4}+0,53 X_{5}$, where, $Z_{i}$ is the score obtained by the firm, $X_{1}$ is working capital weighted by total assets, $X_{3}$ is the return on assets (ROA), $X_{4}$ is the market value of total liabilities, and $X_{5}$ is the asset turnover. The calculations of these parameters are presented in Table 2.

Table 2

Model parameters of Altman, Baydia, and Dias (1979).

$$
\begin{aligned}
& X_{1}=\frac{\text { (Current Assets } \left._{i t}-\text { Current Liabilities }_{i t}\right)}{\text { Total Assets }_{i t}} \quad X_{4}=\frac{{\text { Market } \text { Value }_{i t}}_{\text {Total Liabilities }}}{\text { it }} \\
& X_{3}=\frac{\text { Earnings Before Interest and Taxes }_{i t}}{\text { Total Assets }_{i t}} \quad X_{5}=\frac{\text { Sales }_{i t}}{\text { Total Assets }_{i t}}
\end{aligned}
$$

According to Silva et al. (2012), this model is more reliable for predicting bankruptcies in firms in Brazil. However, the coefficients of this equation were estimated for a specific sample, in a specific period and situation, and should not be replicated for other samples and periods; otherwise, the firms would be wrongly classified as insolvent. For this reason, in this study, a

$$
\boldsymbol{p}_{\boldsymbol{i}}=\boldsymbol{P}\left(\boldsymbol{Z}_{\boldsymbol{i}}=\mathbf{1}\right)=\frac{1}{1+e^{-\left(-0,854-1,555 X_{1 i}-2,278 X_{3 i}+0,002 X_{4 i}-0,234 X_{5 i}\right)}}
$$

If the company has a $Z_{i}$ rated in the upper quintile of this sample, i.e. $P\left(Z_{i}\right)>0.80$, it is assumed that it has similar characteristics to companies with continuity problems, as in Altman, Baydia, and Dias (1979). When $P\left(Z_{i}\right) \leq 0.80$, it is understood that the firm is in probit model is estimated, as in Altman, Baydia, and Dias (1979), considering the companies in the sample that filed for bankruptcy or judicial reorganization between 2010 and 2015 (23 firms), which gives new coefficients for the parameters $X_{1}, X_{3}, X_{4}$, and $X_{5}$ used in Equation 2 to identify the likelihood of firm insolvency, where $P\left(Z_{i}=1\right)$. the group whose profile indicates continuity of its operations. In the other estimated models, this indicator is transformed into a dummy variable that assumed the value 1 (one) when $P(Z i)>0.80$, and the value 0 (zero) when $P(Z i) \leq 0.80$. 
To calculate the M-score, the Beneish (1999) model is used, which relates the firm's potential to manipulate its results with its financial characteristics, where $M=-4.84+0.920 A R S I+$ $0.528 G M I+0.404 A Q I+0.892 S G I+0.115 D E P I$ $-0.172 S G A I-0.327 L V G I+4.679 T A T A$, where $A R S I$ is the accounts receivables to sales index,
$G M I$ is the gross margin index, $A Q I$ is the asset quality index, $S G I$ is the sales growth index, $D E P I$ is the depreciation index, $S G A I$ is the sales, general, and administrative expenses ratio, $L V G I$ is the leverage ratio, and TATA is the total accruals to total assets. The calculations of these parameters are presented in Table 3.

Table 3

\section{Model parameters of Beneish (1999).}

\begin{tabular}{|c|c|}
\hline$A R S I=\frac{\left(\text { Receivables }_{i t} / \text { Sales }_{i t}\right)}{\left(\text { Receivables }_{i t-1} / \text { Sales }_{i t-1}\right)}$ & $G M I=\frac{\text { Gross }_{\operatorname{Margin}_{i t}}}{\text { Gross } \operatorname{Margin}_{i t-1}}$ \\
\hline$A Q I=\frac{1-\left(\left(\text { Current Assets }_{i t}+P P \& E_{i t}\right) / \text { Total Assets }_{i t}\right)}{1-\left(\left(\text { Current Assets }_{i t-1}+P P \& E_{i t-1}\right) / \text { Total Assets }_{i t-1}\right)}$ & $S G I=\frac{\text { Sales }_{i t}}{\text { Sales }_{i t-1}}$ \\
\hline$D E P I=\frac{\text { (Depreciation }_{i t} /\left(\text { Depreciation }_{i t}+P P \& E_{i t}\right)}{\text { (Depreciation }_{\text {it }-1} /\left(\text { Depreciation }_{i t-1}+P P \& E_{i t-1}\right)}$ & LVGI $=\frac{\text { Total Liabilities }_{i t} / \text { Total Assets }_{\text {it }}}{\text { Total Liabilities }}$ \\
\hline 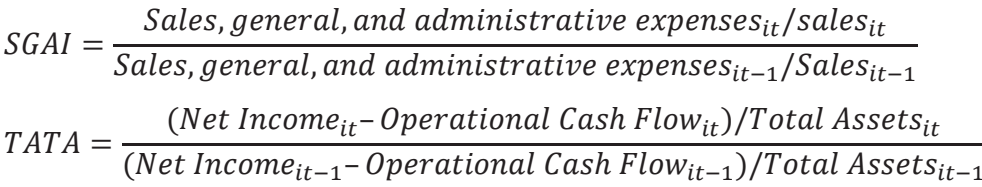 & \\
\hline
\end{tabular}

However, similarly to Altman, Baydia, and Dias (1979), Beneish (1999) estimated the coefficients of these parameters for a specific sample at a specific time and in a specific situation. Thus, the coefficients of the Beneish (1999) model are reestimated by means of a probit regression model considering the firms in this sample that had filings with the Brazilian Securities Commission (CVM) requesting the rewriting or republishing of their financial statements in the period from 2010 to 2015 (16 companies), which gave rise to new coefficients, used in Equation 3 to estimate the likelihood of the firm manipulating its results, given by $P(M i=1)$.

$$
=\boldsymbol{P}\left(\boldsymbol{M}_{\boldsymbol{i}}=\mathbf{1}\right)=\frac{1}{1+e^{-(-1,635+0,251 D S R I+0,462 G M I-0,231 A Q I+0,114 S G I-1,075 D E P I+0,139 S G A I+0,014 L V G I+0,058 T A T A)}}
$$

When $P\left(M_{i}\right)$ is located in the highest quintile of the sample, i.e. $P(M i)>0.80$, there is a greater possibility of earnings manipulation in the company, as identified by Beneish (1999) and Razali and Arshad (2014). In the second regression of this study, this indicator is transformed into a dummy variable that assumed the value 1 (one) when $P(M i)>0.80$, and the value 0 (zero) when $P(M i) \leq 0.80$.
Thus, only after identifying $P\left(Z_{i}\right)$ and $P(M i)$ is it possible to identify the likelihood of fraudulent financial reporting $(F F R i)$, similarly to in Razali and Arshad (2014), by means of a dummy variable that assumed the value 1 (one) when, at the same time, the company is in the highest quintile for bankruptcy prediction $\left(P\left(Z_{i}\right)>0.80\right)$ and the likelihood of earnings manipulation $P\left(M_{i}\right)>0.80$ ), and assumed the 
value 0 (zero) in the opposite cases (see Figure 1). Following these estimates, the influence of the corporate governance structure on FFR is analyzed, as well as the influence of this structure on bankruptcy prediction and earnings manipulation, as described in subsection 3.1.

\section{Results}

The analysis of the results begins with the estimates of the variables of interest of this study, namely: bankruptcy prediction (Z-score), earnings manipulation (M-score), and the likelihood of fraudulent financial reporting (FFR). Table 4 shows that of the total year-observations analyzed, the likelihood of fraud is identified in $5.5 \%$ of them. That is, in less than one-tenth of the cases evidence of bankruptcy prediction and earnings manipulation are identified at the same time. This percentage is lower than that found by Razali and Arshad (2014) in the Malaysian market (21\%); however, we can highlight important differences between this study and that one, since Razali and Arshad (2014) used the Beneish (1999) model for the M-score, but a different Altman model for the $\mathrm{Z}$-score. Moreover, an advantage of this study is that new fundamental equations for these two models are estimated for the sample analyzed, giving greater robustness and reliability to the estimation of $Z$ and $M$ in the Brazilian market.

The FFR in the period analyzed is based on the likelihood that the firms will show signs of bankruptcy and manipulation of their results in their financial statements. In about $16.91 \%$ of cases, there is evidence of bankruptcy prediction $P(Z i)>0.80)$ and in $17.73 \%$ of the observations there is evidence of earnings manipulation $(P(Z i)>0.80)$. Note that these are averages of the occurrence of these phenomena, not the averages of the $\mathrm{Z}$ and $\mathrm{M}$ scores. Above all, it is important to highlight that we are dealing with "probabilities," not the determination of these events.

Table 4

Descriptive statistics of the variables studied. 2010-2015.

\begin{tabular}{|c|c|c|c|c|c|}
\hline Variable & Mean & Median & Standard Deviation & Minimum & Maximum \\
\hline & 0.0550 & - & - & - & - \\
\hline Z-score & 0.1691 & - & - & - & - \\
\hline \multirow[t]{10}{*}{ M-score } & 0.1773 & - & - & - & - \\
\hline & 7.0487 & 7.0000 & 2.7430 & 1.0000 & 24.0000 \\
\hline & 0.1845 & 0.1428 & 0.2059 & 0.0000 & 1.0000 \\
\hline & 0.0806 & 0.0625 & 0.0857 & 0.0000 & 0.6666 \\
\hline & 0.7808 & 1.0000 & 0.4137 & 0.0000 & 1.0000 \\
\hline & 0.0171 & 0.0009 & 0.1447 & 0.0000 & 5.1470 \\
\hline & 0.1101 & 0.0138 & 1.0132 & 0.0000 & 30.1156 \\
\hline & 0.8336 & 0.0009 & 1.4723 & 0.0000 & 7.0000 \\
\hline & 0.3947 & 0.0000 & 0.4889 & 0.0000 & 1.0000 \\
\hline & 21.4907 & 21.6926 & 2.2252 & 10.8159 & 29.3852 \\
\hline
\end{tabular}

Note: FFR is the likelihood of fraudulent financial reporting; $Z$-score is the bankruptcy prediction; $M$-score is the earnings manipulation; Bsize is the size of the board of directors; Bind is the percentage of independent directors on this board; Bwom is the percentage of women on the board; Ndual is the absence of duality of CEO and Chairman positions; Bcom is the total compensation of directors; EAcom is the compensation paid to independent auditing firms; ACsize is the size of the audit committee; NMlistit is a listing in the New Market segment; and SIZEit is the firm's size. 
Table 4 also shows the descriptive statisticTable 4 also shows the descriptive statistics of the variables that represent the corporate governance structure. The average size of the board of directors (Bsize) is about 7 members, as in Holtz and Sarlo Neto (2014), thus being within the ideal size for a good corporate governance structure, which is between 5 and 9 members (Lipton \& Lorsch, 1992; Vafeas, 2005; Razali \& Arshad, 2014). It is also noteworthy that in 14 instances there are boards with only 1 or 2 member(s), even though firms in Brazil are required to have a minimum of 3 members, according to Law No. 6,404/1976. In such cases, an error in the database or lack of information is not ruled out.

On average, $18.45 \%$ of the companies' boards are formed of independent members. This indicates weakness in the corporate governance structure of the firms, especially due to the possible misalignment of interests between investors and managers, increasing the chances of information asymmetry (Razali \& Archad, 2014), which may lead to compromised accounting information quality (Beasley, 1996). In Brazil, the B3 requires companies listed in the New Market segment, the highest level of governance of the stock exchange, to have a minimum of $20 \%$ independent members on their boards of directors. Regarding the participation of women in the board, the average is $8.06 \%$, which is higher than that found by Martins, Mazer, Lustosa, and Paulo (2012), of $6.17 \%$ for banks in Brazil. In this case, the B3 does not assign firms a minimum number of women.

Non-duality of CEO and Chairman positions (Ndual) is found in $78.08 \%$ of cases, indicating that in most companies the directors and chairmen of the boards are exclusively dedicated to their duties, thus avoiding the concentration of power and unilateral decisions (Bebchuk \& Fried, 2004; Chhaochharia \& Grinstein, 2009). The average of total compensation of the board (Bcom) is $1.71 \%$ of the total assets of the firms, while the average of external auditor compensation (EAcom) is $11.01 \%$ of total assets. However, in both cases, it is possible to verify that such compensations vary significantly between companies, considering the differences between these averages in relation to the medians of these variables. The medians are more stable.

The size of the audit committee (ACsize) is less than 1 member (0.8336), especially due to the non-obligation of this committee in all companies, which means that most do not have one, which is also indicative of weak corporate governance structures, as the minimum size indicated in the literature is 3 members (Abbott, Parker, \& Peters, 2004; Vafeas, 2005). Regarding a listing in the New Market segment (NMlist), we find that about $39.47 \%$ of the year-observations refer to firms listed at the highest corporate governance level of the stock market.

\section{I Influence of Corporate Governance}

To analyze the influence of the corporate governance structure on the likelihood of fraud and its variables (bankruptcy prediction and earnings manipulation), three probit bivariate regression models with panel data are estimated. The first model relates the explained variable FFR to the corporate governance structure. Then, as a robustness test, two other models relate indicators of bankruptcy prediction and earnings manipulation with governance. Table 5 presents the results of these models, whose statistics indicate that they are robust to econometric assumptions. In all estimated models, dummy variables are included to control time and sector effects. However, due to the number of variables and considering that the variables of interest of this study are the corporate governance practices, in this table, it is only indicated that such effects are controlled.

After identifying the likelihood of FFR, as shown in Figure 1, its relationship with the governance structure is analyzed. Considering that this structure influences adverse selection and moral hazard situations, reducing information asymmetry (Jensen, 1993), it is reasonable to expect corporate governance practices, as a whole, 
to have a negative effect on FFR. However, in the sample analyzed in this study it can be seen that only half of the practices effectively had a negative influence on FFR, thus supporting the expected relationships. The other half does not present statistical significance regarding the set of practices analyzed.

Table 5 shows that independence of the board of directors (Bind) presents a negative and significant relationship (-0.056), indicating that greater independence of its members reduces the chances of fraud in the financial reports. This result is consistent with Xie, Davidson, and Dadalt (2003) and Siladi (2006), who point out that such independence improves the effectiveness of management monitoring, reducing agency problems (Jensen \& Meckling, 1976) and the likelihood of earnings management.

Similarly, the increased participation of women on this board also reveals a negative influence on FFR (-0.043), indicating that the existence of women on the board improves its efficiency, as noted by Boulouta (2013). This confirms the IBGC's concern about increasing the plurality of boards (IBGC, 2015), especially regarding the gender of its members. Therefore, in addition to broadening the individual characteristics of its members and fostering richer debates, the presence of females is a factor associated with a reduction in FFR.

Also, according to Table 5, the compensation of the board of directors $(\mathrm{Bcom})$ is also a determinant factor of a lower likelihood of fraud (-24.829). This variable is actually the one with the greatest negative marginal effect on FFR. Oliva and Albuquerque (2007) note that board compensation is an incentive for management to align its objectives with those of shareholders. And our findings reveal that this compensation actually has a negative association with the likelihood of fraudulent financial reporting, as it reduces the agency problems pointed out by Jensen and Meckling (1976). As a result, we note that more independent, more female, and better-paid boards are more effective at mitigating the likelihood of fraud in corporate financial reporting.

Similar to Bsize, the size of the audit committee (ACsize) also reveals a negative influence on FFR (-0.336), indicating that increasing the size of this committee reduces the chances of financial reporting fraud, especially due to more comprehensive and effective monitoring, which is consistent with the literature (Coram, Ferguson, \& Moroney, 2006; Law, 2011; Razali \& Arshad, 2014). As noted by Ken, Routledgea, and Steward (2010), it can be seen that in Brazil its size influences the quality of financial statements, indicating greater diversity of knowledge and effectiveness of this committee. As for the other variables, this joint analysis cannot confirm their influence on FFR, as they are not significant in the first estimated model. 
Table 5

Relationship between the variables of interest and corporate governance structure. 2010-2015.

\begin{tabular}{|c|c|c|c|c|c|c|}
\hline \multirow{2}{*}{ Variable } & \multicolumn{2}{|c|}{ FFR } & \multicolumn{2}{|c|}{ Bankruptcy } & \multicolumn{2}{|c|}{ Manipulation } \\
\hline & Coefficient & Z Statistic & Coefficient & Z Statistic & Coefficient & Z Statistic \\
\hline Constant & 3.239 & 1.39 & 5.876 & $5.27^{* * *}$ & -3.791 & $-3.44^{* * *}$ \\
\hline Bsize & -0.087 & -1.54 & -0.056 & $-1.83^{*}$ & 0.021 & 0.77 \\
\hline Bind & -0.056 & $-3.24^{* * *}$ & 0.001 & 0.19 & -0.001 & -0.06 \\
\hline Bwom & -0.043 & $-2.52^{* *}$ & -0.037 & $-4.44^{* * *}$ & -0.004 & -0.57 \\
\hline Ndual & -0.347 & -1.46 & -0.448 & $-3.51^{* * *}$ & 0.049 & 0.43 \\
\hline Bcom & -24.829 & $-2.71^{* * *}$ & -4.644 & -0.98 & -9.101 & $-2.02^{* *}$ \\
\hline EAcom & 2.573 & 0.61 & -1.872 & -0.87 & 3.109 & 1.56 \\
\hline ACsize & -0.336 & $-1.90^{*}$ & 0.030 & 0.52 & -0.085 & $-1.77^{* *}$ \\
\hline NMlist & -4.609 & -0.02 & 0.047 & 0.28 & -0.332 & $-2.28^{* *}$ \\
\hline SIZE & -0.132 & -1.28 & -0.268 & $-5.02^{* * *}$ & 0.103 & $1.99^{* *}$ \\
\hline Dummies-year & \multicolumn{2}{|c|}{ Yes } & \multicolumn{2}{|c|}{ Yes } & \multicolumn{2}{|c|}{ Yes } \\
\hline Dummies-Sector & \multicolumn{2}{|c|}{ Yes } & \multicolumn{2}{|c|}{ Yes } & \multicolumn{2}{|c|}{ Yes } \\
\hline $\mathrm{R}^{2}$ & \multicolumn{2}{|c|}{0.550} & \multicolumn{2}{|c|}{0.396} & \multicolumn{2}{|c|}{0.163} \\
\hline Log Likelihood & \multicolumn{2}{|c|}{-86.574} & \multicolumn{2}{|c|}{-292.824} & \multicolumn{2}{|c|}{-404.540} \\
\hline Chi square & \multicolumn{2}{|c|}{$211.830^{* * *}$} & \multicolumn{2}{|c|}{$384.250^{* * *}$} & \multicolumn{2}{|c|}{$157.630^{* * *}$} \\
\hline No Firms & \multicolumn{2}{|c|}{96} & \multicolumn{2}{|c|}{187} & \multicolumn{2}{|c|}{160} \\
\hline No Observations & \multicolumn{2}{|c|}{540} & \multicolumn{2}{|c|}{1.054} & \multicolumn{2}{|c|}{897} \\
\hline
\end{tabular}

Note: FFR is the likelihood of fraudulent financial reporting; Bankruptcy is the likelihood of bankruptcy prediction, represented by $P\left(Z_{i}\right)$; Manipulation is the likelihood of earnings manipulation, represented by $P\left(M_{i}\right)$; Bsize is the size of the board of directors; Bind is the percentage of independent directors on this board; Bwom is the percentage of women on the board; Ndual is the absence of duality of CEO and Chairman positions; Bcom is the total compensation of directors; EAcom is the compensation paid to independent auditing firms; ACsize is the size of the audit committee; NMlist is a listing in the New Market segment; and $S I Z E_{i t}$ is the firm's size. ${ }^{*}$ is significant at $10 \%,{ }^{* *}$ at $5 \%$, and ${ }^{* * *}$ at $1 \%$.

The second model analyzes the relationship between bankruptcy prediction $\left(P\left(Z_{i}\right)\right)$ and the corporate governance structure. The size of the board of directors (Bsize) presents a negative and significant relationship (-0.056) with bankruptcy prediction. The participation of women on the board (Bwom) and CEO and Chairman nonduality (Ndual) also have negative influences on bankruptcy prediction, with coefficients of -0.037 and -0.448 , respectively. This complimentary analysis confirms the findings for the FFR model, revealing that part of the mitigation of FFR is also explained by the influence of the corporate governance structure of companies on their likelihood of bankruptcy. Also, we note that the firm's size $(S I Z E)$ is also a determinant for reducing this likelihood $(-0.286)$, although it is not for FFR.
This indicates that larger boards, greater female participation, no joint $\mathrm{CEO}$ and Chairman positions, and larger companies are related to a lower likelihood of bankruptcy, which is consistent with Lipton and Lorsch (1992), Boulouta (2013), Chhaochharia and Grinstein (2009), and Martins and Paulo (2014). On the other hand, the other aspects inherent to the board of directors and, especially, to audits, have no significant coefficients and, therefore, no inferences can be made about them.

The third model analyzes the relationship between the likelihood of earnings manipulation $\left(P\left(M_{i}\right)\right)$ and the corporate governance structure. Among the variables related to the board of directors, only Bcom shows a negative and significant relationship (-9.101), confirming the assumption that some mandatory increases in 
company disclosure and consequent reductions in information asymmetry can be explained by increased spending on senior management (Hermalin \& Weisbach, 2012). Also, a significant negative relationship $(-0.085)$ with the size of the audit committee (ACsize) can be noted, contributing to the expectation that the audit committee can contribute to better quality accounting information. Since there are more auditors in the company, it is natural for there to be more barriers to earnings manipulation. The presence of an audit committee can positively influence business performance (Arshad, Razali, \& Bakar, 2014), prevent earnings management, and contribute to the quality of financial reporting (Abbott, Parker, \& Peters, 2004; Vafeas, 2005; Ken, Routledgea, \& Steward, 2010).

Regarding the classification of firms in the New Market segment, the findings of this study reveals its negative influence on the likelihood of earnings manipulation (-0.332), reinforcing previous empirical evidence that companies in this segment can mitigate earnings management and reduce problems of information asymmetry in the Brazilian market (Moreiras et al., 2012; Piccoli et al., 2014).

However, only firm size (SIZE) shows a positive and significant relationship with the likelihood of earnings manipulation (0.103), suggesting that in the sample analyzed the companies with the greatest total assets are those most likely to manipulate their earnings. Although this is not an integral practice of corporate governance structure and is considered a control variable for the size effect, this finding is surprising because larger firms are expected to be less likely to manipulate earnings as they tend to have a bigger and better governance structure. However, this finding may be explained by the natural accruals of firms, arising from their operating activities. And this explanation is confirmed by the fact that SIZE has a negative relationship with the likelihood of bankruptcy and a non-significant relationship with FFR. The other variables are not statistically significant and, therefore, it is not possible to make inferences about them.

\section{Conclusion}

From these findings, it is evident that the corporate governance structure of firms in Brazil is effective in mitigating the likelihood of fraudulent financial reporting (FFR), but especially that each practice of this structure plays a different role in relation to FFR and the likelihood of bankruptcy and earnings manipulation.

We note that the results of the estimated model for the likelihood of fraud are supported by complementary analyses for bankruptcy prediction and earnings manipulation. From the estimated models, we note that, together, the main corporate governance practices of companies can mitigate FFR, as well as bankruptcy and earnings manipulation. It can also be seen that, among the practices that are part of the corporate governance structure, those related to the board of directors are more efficient in mitigating bankruptcy problems, while those related to auditing are more efficient in mitigating earnings manipulation. These findings, in turn, are consistent with both the legal attributions of each of these elements, as well as with the previous literature that sees corporate governance as an important mechanism for mitigating fraud and information asymmetry.

Regarding the expected relationships between each corporate governance practice and the likelihood of fraud, bankruptcy, and earnings manipulation, it can be concluded that only external auditor compensation (EAcom) does not present significance and clarity of association in any of the three estimated models. All other practices present negative and significant relationships in at least one of the estimated models, either mitigating FFR, bankruptcy, or earnings manipulation. For this reason, it is reasonable to consider that corporate governance is effective in mitigating the existence of fraudulent financial reports in the Brazilian market.

The main contribution of this study to academia is the presentation of evidence regarding FFR and its relationship with the corporate governance of firms in Brazil, which, as far as we know, has not previously been explored by 
a similar research method, this being the first study in that regard. This is especially due to its methodological robustness, considering that it uses established models already applied to the Brazilian market to estimate new and current parameters for identifying the possibilities of bankruptcy and earnings manipulation, to identify FFR for the first time in this market. This evidence is also relevant for the market, as these findings enable its agents to identify the relevance of corporate governance practices for mitigating fraud, bankruptcy, and information asymmetry problems, assisting them in more efficient investment decisions, as well as being useful to the regulatory bodies in this market.

Finally, this study involves certain limitations, particularly in the scope of the variables inherent to corporate governance due to the sample size and time horizon, as well as it not capturing depreciation for the estimation of the M-score, since most financial statements provide only the net value of PP\&E. Moreover, there are limitations in the models used, which are a simplification of a complex reality. However, given the scarcity of the topic in the literature, the methodological robustness of the study, and the importance of its findings, such limitations do not invalidate the study, which is relevant to the related literature.

We also emphasize that the statistics only indicate chances of fraudulent financial reporting, bankruptcy, and earnings manipulation. They are merely evidence observed from economic-financial models that seek to provide an approximation of a complex reality and, therefore, it is not the intention of this study to point out companies that are in bankruptcy or even manipulating or rigging their reports.

\section{References}

Abbott, L. J., Parker, S., \& Peters, G. F. (2004). Audit committee characteristics and restatements. Auditing: A Journal of Practice \& Theory, 23(1), 69-87.
Altman, E. I. (1968). Financial ratios, discriminant analysis and the prediction of corporate bankruptcy. The Journal of Finance, 23(4), 589-609.

Altman, E. I., Baydia, T. K. N., \& Dias, L. M. R. (1979). Previsão de problemas financeiros em empresas. Revista de Administração de Empresas, 19(1), 17-28.

Alzoubi, E. S. S., \& Selamat, M. H. (2012). The effectiveness of corporate governance mechanisms on constraining earning management: literature review and proposed framework. International Journal of Global Business, 5(1), 17-35.

Arshad, R., Iqbal, S. M., \& Omar, N. (2015). Prediction of Business Failure and Fraudulent Financial Reporting: Evidence from Malaysia. Indian Journal of Corporate Governance. 8(1), 34-53.

Arshad, R., Razali, W. A. A. W., \& Bakar, N. A. (2014). Disclosure of Corporate Governance Structure and Financial Vulnerability. In: Proceedings of World Business and Economics Research Conference. Auckland, New Zealand. 2014.

Beasley, M. S. (1996). An empirical analysis of the relation between the board of director composition and financial statement fraud. Accounting Review, 71(4), 443-465.

Bebchuk, L. A., \& Fried, J. M. (2004). Pay without performance: the unfulfilled promise of executive compensation. Cambridge: Harvard University, 2004.

Beneish, M. D. (1999). The detection of earnings manipulation. Financial Analysts Journal, 55(5), 24-36.

Boulouta, I. (2013). Hidden connections: The link between board gender diversity and corporate social performance. Journal of Business Ethics, 113(2), 185-197. 
Chhaochharia, V., \& Grinstein, Y. (2009). CEO compensation and board structure. The Journal of Finance, 64(1), 231-261.

Coelho, A. N. B., Lima, N. C., Souza, G. H. S., Oliveira, S. V. W. B., \& Oliveira, M. M. B. (2015). A responsabilidade da Auditoria Independente na fraude contábil do banco PanAmericano. Revista de Auditoria, Governança e Contabilidade, 3(7), 53-70.

Coram, P., Ferguson, C., \& Moroney, R. (2006). The value of internal audit in fraud detection. Department of Accounting and Business Information Systems, 3010, 1-32.

Cunha, P. R., Silva, J. O., \& Fernandes, F. C. (2013). Pesquisas sobre a lei Sarbanes-Oxley: uma análise dos journals em língua inglesa. Enfoque: Reflexão Contábil, 32(2), 37-51.

Dalmácio, F. Z., \& Rezende, A. J. (2008). A relação entre o timeliness e a utilidade da informação contábil e os mecanismos de Governança Corporativa: evidências no mercado acionário brasileiro. Revista de Administração e Contabilidade da Unisinos, 5(3), 163-174.

DeAngelo, L. E. (1981). Auditor size and audit quality. Journal of Accounting and Economics, 3(3), 183-199.

Dechow, P. M., Ge, W., Larson, C. R., Sloan, R. G. (2011). Predicting material accounting misstatements. Contemporary accounting research, 28(1), 17-82.

Francis, J. R. (1984) The effect of audit firm size on audit prices. Journal of Accounting and Economics, 6, 133-151.

Hermalin, B. E., \& Weisbach, M. S. (2012). Information disclosure and corporate governance. The Journal of Finance, 67(1), 195-233.

Holtz, L., \& Sarlo Neto, A. (2014). Efeitos das Características do Conselho de Administração sobre a Qualidade da Informação Contábil no
Brasil. Revista Contabilidade \& Finanças, 25(66), 255-266.

IBGC - Instituto Brasileiro de Governança Corporativa. (2015). Código das Melhores Práticas de Governança Corporativa. 4 ed. São Paulo: IBGC.

Jensen, M. C. (1993). The modern industrial revolution, exit, and the failure of internal control systems. The Journal of Finance, 48(3), 831-880.

Jensen, M. C., \& Meckling, W. H. Theory of the firm: Managerial behavior, agency costs, and ownership structure. Journal of Financial Economics, 3(4), 305-360.

Kamal, M. E. M, Salleh, M. F. M., \& Ahmad, A. (2016). Detecting Financial Statement Fraud by Malaysian Public Listed Companies: The Reliability of the Beneish M-Score Model.

Journal Pengurusan, 46, 23-32.

Kent, P., Routledge, J., \& Stewart, J. (2010). Innate and discretionary accruals quality and

corporate governance. Accounting and Finance, 50(1), 171-195.

Law, P. (2011). Corporate governance and no fraud occurrence in organizations: Hong Kong evidence. Managerial Auditing Journal, 26(6), 501-518.

Lipton, M., \& Lorsch, J. W. (1992). A modest proposal for improved corporate governance. The Business Lawyer, 48(1), 59-77.

Martins, O. S., Mazer, L. P., Lustosa, P. R. B., \& Paulo, E. (2012). Características e Competências dos Conselhos de Administração de Bancos Brasileiros e suas Relaçôes com seus Desempenhos Financeiros. Revista Universo Contábil, 8(3), 40-61.

Martins, O. S., \& Paulo, E. (2014). Assimetria de informação na negociação de ações, características econômico-financeiras e governança corporativa 
no mercado acionário brasileiro. Revista Contabilidade \& Finanças, 25(64), 33-45.

Mehta, A., \& Bhavani, G. (2017). Application of Forensic Tools to Detect Fraud: The Case of Toshiba. Journal of Forensic and Investigative Accounting. 9(1), 692-710.

Moreiras, L. M. F., Tambosi Filho, E., \& Garcia, F. G. (2012). Dividendos e informação assimétrica: análise do novo mercado. Revista de Administração, 47(4), 671-682.

Murcia, F. D., \& Borba, J. A. (2005). Um estudo das fraudes contábeis sob duas óticas: jornais econômicos versus periódicos acadêmicos no período de 2001-2004. Revista de Contabilidade do Mestrado em Ciências Contábeis da UERJ, 10(2), 99-114.

Murcia, F. D., Borba, J. A., \& Schiehll, E. (2008). Relevância dos red flags na avaliação do risco de fraudes nas demonstraçóes contábeis: a percepção de auditores independentes brasileiros. Revista Universo Contábil, 4(1), 25-45.

Oliva, E. D. C., \& Albuquerque, L. G. (2007). Sistema de remuneração de executivos e conselheiros como suporte à estrutura de governança corporativa. Revista Base, 4(1), 61-73.

Omar, N., Koya, R. K., Sanusi, Z. M., \& Shafie, N. A. (2014). Financial Statement Fraud: A Case Examination Using Beneish Model and Ratio Analysis. International Journal of Trade, Economics, and Finance, 5(2), 184-186.

Peleias, I. R., Segreti, J. B., \& Costa, C. A. (2009). Comitê de Auditoria ou órgãos equivalentes no contexto da Lei Sarbanes-Oxley: estudo da percepção dos gestores de empresas brasileiras emitentes de American Depositary ReceiptsADRs. Contabilidade Vista \& Revista, 20(1), 41-65.

Perera, L. C. J., Freitas, E. C., \& Imoniana, J. O. (2014). Avaliação do sistema de combate às fraudes corporativas no Brasil. Revista Contemporânea de Contabilidade, 11(23), 03-30.

Piccoli, P. G. R., Souza, A., \& Silva, W. V. (2014). As práticas de governança corporativa diminuem o gerenciamento de resultados? Evidências a partir da aversão na divulgação de prejuízos e de queda nos lucros. Revista Contemporânea de Contabilidade, 11(22), 141-162.

Razali, W. A. A. W. M., \& Arshad, R. (2014). Disclosure of corporate governance structure and the likelihood of fraudulent financial reporting. Procedia-Social and Behavioral Sciences, 145(25), 243-253.

Rezende, A. J., \& Dalmácio, F. Z. (2015). Práticas de Governança Corporativa e Indicadores de Performance dos Clubes de Futebol: uma Análise das Relaçôes Estruturais. Contabilidade, Gestão e Governança, 18(3), 105-125.

Santana, A. G., Bezerra, F. A., Teixeira, S. A., Cunha, P. R. (2014). Auditoria independente e a qualidade da informação na divulgação das demonstrações contábeis: estudo comparativo entre empresas brasileiras auditadas pelas Big Four e Não Big Four. Revista de Contabilidade do Mestrado em Ciências Contábeis da UERJ, 19(3), 70-87.

Santos, N. L., Martins, C. M. F., Martins, P. L., Santos Neta, M. C., \& Chain, C. P. (2013). Avaliação dos analistas de mercado sobre a relevância dos trabalhos dos auditores independentes na análise financeira das sociedades anônimas (SA) de capital aberto. REA - Revista Eletrônica de Administração, 12(1), 31-47.

Siladi, B. (2006). The role of non-executive directors in corporate governance: An evaluation. Faculty of Business and Enterprise, Swinburne University of Technology.

Silva, A. M. C., Braga, E. C., \& Laurencel, L. C. (2009). A corrupção em uma Abordagem Econômico-Contábil e o Auxílio da Auditoria 
como Ferramenta de Combate. Contabilidade Vista \& Revista, 20(1), 95-117.

Silva, J. O., Wienhage, O., Souza, R. P. S., Lyra, R. L. W. C., \& Bezerra, F. A. (2012). Capacidade preditiva de modelos de insolvência com base em números contábeis e dados descritivos. Revista de Educação e Pesquisa em Contabilidade, 6(3), 246-261.

Silva, L. M. (2007). A influência da lei SarbanesOxley e do código civil brasileiro nos controles internos de empresas localizadas no Brasil. Dissertação de Mestrado. Universidade do Vale do Rio dos Sinos, São Leopoldo, Brasil.

Tajo, C. \& Herawati, N. (2015). Application of Beneish M-Score Models and Data Mining to Detect Financial Fraud. Procedia - Social and Behavioral Sciences, 211, 924-930.

Vafeas, N. (2005). Audit committees, boards, and the quality of reported earnings. Contemporary Accounting Research, 22(4), 1093-1122.

Xie, B., Davidson, W. N., \& Dadalt, P. J. (2003). Earnings management and corporate governance: the role of the board and the audit committee. Journal of Corporate Finance, 9(3), 295-316.

Wells, J. T. (2011). Corporate fraud handbook: prevention and detection. 3 ed. New Jersey: Wiley. 


\section{Supporting Agencies:}

National Council for Scientific and Technological Development (CNPq)

\section{Authors:}

1. Orleans Silva Martins, P.h.D in Controllership and Accounting, University of São Paulo, Faculty of Economics, Administration and Accounting, São Paulo, Brazil.

E-mail: orleansmartins@ccsa.ufpb.br

ORCID

(iD) 0000-0002-4966-0347

2. Raul Ventura Júnior, Master of Accounting, Federal University of Paraíba, Department of Finance and Accounting, Paraíba, Brazil.

E-mail: rjventura@yahoo.com.br

ORCID

(D) 0000-0003-0095-216X

\section{Contribution of each author}

\begin{tabular}{lcc}
\hline Contribution & Orleans Martins & Raul Ventura \\
\hline 1. Definition of research problem & $\sqrt{ }$ & $\sqrt{ }$ \\
2. Development of hypotheses or research questions (empirical studies) & $\sqrt{ }$ & $\sqrt{ }$ \\
3. Development of theoretical propositions (theoretical work) & $\sqrt{ }$ & $\sqrt{ }$ \\
4. Theoretical foundation / Literature review & $\sqrt{ }$ & $\sqrt{ }$ \\
5. Definition of methodological procedures & $\sqrt{ }$ \\
6. Data collection & $\sqrt{ }$ & $\sqrt{ }$ \\
7. Statistical analysis & $\sqrt{ }$ & $\sqrt{ }$ \\
8. Analysis and interpretation of data & $\sqrt{ }$ \\
9. Critical revision of the manuscript & $\sqrt{ }$ & $\sqrt{ }$ \\
10. Manuscript writing & $\sqrt{ }$ & $\sqrt{ }$ \\
11. Other (please specify which) & & \\
\hline
\end{tabular}

